were taken to that paramount end to which all others should surely be subservient.

Necessary actions or at least directions are now so well known that I need not repeat them before an enlightened scientific audience. Suffice it to say that, were it not for the indulgence and profligacy of which we are all to some extent guilty, we would not be threatening increasingly the availability of sufficient space and raw materials to support the desirable numbers of humans inhabiting the Earth, we would not be threatening the stratospheric ozone shield and stability of climates, we would not be threatening the seas and limited fresh waters increasingly with pollution, or the soils and forests with salinity and acidity: all could be arranged to save our world.

So let us look to some such campaign as the further evolution of Mankind - to a new subspecies or at least forma or other taxon that we may dream of as Homo supersapiens - preferably by persuasive demonstration, failing that by legal processes, or even by genetic manipulation or yet other means, and regardless of how difficult and costly those means might have to be.

Already we have had in being for some years past the World Council For The Biosphere, of which Sir John Burnett is Executive Secretary. He will be well known to many of you as the recent Principal and Vice-Chancellor of the University of Edinburgh who was, until earlier this year, Acting Chairman of the Nature Conservancy Council; and if no major body takes up such a challenging theme beforehand, I plan to propose it to the World Council For The Biosphere for active promotion at latest by the time I relinquish the founding chairmanship of that body by statute in the Autumn of 1992 .

NichOlas POLUnIN

\title{
Forests in the European USSR
}

The European part of the USSR essentially consists of the rolling East European plain, less than $200 \mathrm{~m}$ above sea-level, which is bordered on practically all sides by mountains: the Caucasus and Crimean Mountains to the south, the Carpathians to the west, the Urals to the east, and the Khibiny Mountains to the north. Thirty-four per cent (192.3 million hectares) of the European USSR is covered by forests. The average coverage currently ranges from $58 \%$ of land in the north to only $2-3 \%$ in the southern regions of the Ukraine and Russia. Seven vegetation zones succeed one another from north to south of the country: Arctic 'desert', tundra, forest tundra, mixed forest, forest steppe, semi-desert, and subtropical vegetation of various types.

Typical of the northern part of the forest zone are evergreen coniferous fir (Abies), pine (Pinus) and spruce (Picea) forests, though larches (Larix) are widespread in the eastern part. Mixed forests of similar coniferous content but also broad-leafed trees such as species of birch (Betula), aspen (Populus), alder (Alnus), oak ( Quercus), linden $=$ lime $($ Tilia $)$, hornbeam $($ Carpinus $)$, ash (Fraxinus), beech (Fagus), maple (Acer), and elm (Ulmus), characterize the Southern part (stretching from the Carpathian Mountains to the Volga and the southern Urals).

The forest steppe stretches in a continuous narrow strip from west to east. Its vegetation consists of alternating small forests of Black Locust (Robinia pseudacacia), and/or oak, maple, elm, etc., species. Steppe vegetation on the lower slopes of the Caucasus gives way higher up to broad-leafed forests mainly of oak and beech, followed still higher by coniferous mountain forest (including Nordmann Fir [Abies nordmanniana] and Oriental Spruce [Picea orientalis]).

Subtropical wetland vegetation occurs in the Kolkhida lowlands on the south-east coast of the Black Sea and in the Lenkoran lowland on the south-west coast of the Caspian Sea: broad-leafed forests of Black Alder (Alnus nigra), various oaks, European Hornbeam (Carpinus betulus), water-elm, and wing-nut, with an abundance of creepers and various shrubby evergreens.

\section{Severe Threats}

Timber reserves in the forests of the European USSR total 24.3 thousand million $\mathrm{m}^{3}$. Stocks of the various main species are reported to increase annually by some
333 million $\mathrm{m}^{3}$. Last year (1990) the total volume of wood stocked, excluding 'improvement felling', was 191.9 million $\mathrm{m}^{3}, 90 \%$ of the felling being carried out in the coniferous forests.

Forests in the northern and northeastern parts of the European USSR have been considerably depleted by clear-felling. The use of heavy machinery compacts the soil and affects the water system. Moreover, industry and 'acid rain' are proving increasingly harmful. Damage to forests in the Kola Peninsula, some Baltic regions, the Urals, and areas around major towns and industrial centres, has been extensive. The effects of 'acid rain' in the main territory are, however, relatively slight.

Following the nuclear disaster at Chernobyl, 3.5 million hectares of forest in the Ukraine, Byelorussia, and the Russian Republic, have suffered varying degrees of pollution. 47,400 hectares of forest suffered dieback in the European USSR last year, largely as a result of changes in the water system, unfavourable weather conditions (drought, humidity, winds, etc.), industrial waste, and damage caused by insects, wild ungulates, rodents, and cryptogamic plant diseases.

Centres of Tortrix viridana and other accompanying Tortricidae have been recorded over an area of 533,500 hectares. Dendrolimus pini, Lymantria monacha, Bupalus piniaria, and other harmful parasites, have also been reported. Root-rot has been recorded over 218,000 hectares. Major concentrations of wood parasites are found close to large towns and industrial centres.

There are 41 State forest conservation stations in the European USSR. In 1989, various measures were taken to control pest populations over 955,700 hectares, i.e. $1 \%$ of the total forest area in the European USSR. Biological forest conservation methods accounted for $71 \%$ of these measures in terms of financial expenditure.

Recently, new parasites have emerged against which no biological treatment is yet available, i.e. the ash weevil in Moldavia, the juniper moth in the Crimea and Krasnodar, and the oak moth which is very widespread in central Ukraine.

\section{Reafforestation}

The European USSR has extensive experience in reafforestation, with some 2 million hectares being replanted every year; of this, some $95 \%$ involves coniferous species. Productive reafforestation is widely 
practised on arable and grazing land, especially in the semi-desert zone. At present, shelterwood has been planted on 4.1 million hectares, but this covers only half of the requirements, and shelterwood planting on a further 2.4 million hectares is thus planned for AD 1991 until AD 2005.

In the European USSR, there are almost 5,000 hectares of seed-tree crops, 70,000 hectares of land permanently set aside for seed-tree crops, and 12,000 hectares of genetic reserves, as well as important seed-improvement centres. There are 16 forest research centres, the most important being the 12 centres of the federal 'Lesproekt' group and the branches of the 'Soyouzguiproleskhoz' institute. A number of organizations set up by the Soviet Academy of Sciences, the Academy of Agriculture, and various higher education establishments, are also studying the problems of forestry and forest management.

The world 'forests' programme, which runs until the year 2010 , is now under way in the USSR. This covers the use of forest resources, reafforestation, afforestation for conservation purposes, seed breeding and genetics, and protection against forest fires, parasites, diseases, human activity, and radiation, among other issues.

\section{Ecological Abnormalities Unavoidable}

While it is impossible to prevent ecological abnormalities, much can be done towards ensuring that human activity respects the distinctive features of biological systems provided there is detailed knowledge of normal and critical states and of ways of restoring the balance. It is vital to focus attention on the causes of environmental problems.

The protection of natural ecosystems and hence of wider ecocomplexes, depends not only on human activity in a variety of sectors but also on scientific research on the various aspects of The Biosphere and its welfare. The study of forest ecosystem processes, and the drawing up of scientific recommendations on protection of the environment call, above all, for interdisciplinary and retrospective research, which is not yet sufficiently developed.

The Soviet State Committee on Forest Resources is ready to cooperate with all the organizations concerned with forestry problems at European, national, and regional, levels. In my view, we need a programme covering the whole of Europe and including, in addition to the pooling of information and collective research on forest ecosystems, practical activities aimed at developing a single system for monitoring European forest resources as part of a world-wide monitoring system. Some measures to that effect have already been introduced for such a purpose. The USSR, the United States, several European countries, Canada, China, and a number of other countries, have already embarked on an active campaign for overall monitoring of their forests.

VASSILI SoUKHIKH, Vice-President
Soviet State Committee
on Forest Resources
Moscow
USSR.

\section{GEMI: Fostering Environmental Excellence by Business World-wide}

\section{Introduction}

In the autumn of 1989 , a work-group on environmental management was formed by the Business Roundtable, a leading US industry coalition composed of more than 200 Concerned Environmental Organizations (CEOs). After examining the environmental practices and needs of its member companies, and consulting outside organizations and other corporations, the workgroup reported findings that pointed to two very real needs for business: (1) that in today's world the existence of corporate and trade association environmental policies in and of themselves is not a satisfactory response to societal demands for corporate responsibility and change, the real need being to define the management systems and behaviour which those policies represent; and (2) that business must provide leadership in defining and effecting responsible corporate and environmental management.

The work-group concluded further that tools to gauge the effectiveness of environmental performance need to be refined, that changes and evolution in domestic or international corporate behaviour are most effectively driven from inside corporations and the business and industrial community, and that a major, or anyway influential, centre of corporate leadership and thinking on the subject of environmental management could contribute significantly to a pro-active business ethic on the environment.

\section{Welcome to GEMI}

Consequently we hail the Global Environmental Management Initiative, or GEMI. Formed out of the findings of the abovementioned work-group, and representing many of the leading US corporations, GEMI is sketching a new archetype for the successful business of the future that incorporates sound environmental management at the highest levels and cooperates closely with government, environmental organizations, and concerned citizens. GEMI's distinction is that it was formed by environmental professionals within the business community according to their hands-on experience in environmental management issues and their vision of how such an organization - and how business as a whole - can work to improve corporate performance on a global scale.

Working with other global organizations such as the United Nations Environment Programme (UNEP), the International Chamber of Commerce (ICC), and the International Environmental Bureau (IEB), GEMI is contributing substantively to the development of a worldwide business ethic on environmental management and sustainable development. Of even greater importance is the fact that GEMI is coordinating environmental management thinking across the entire US industrial spectrum, with parallel business efforts around the world, as well as with academia, and involving both governmental and non-governmental organizations.

\section{Mission of the Movement}

GEMI's mission is simple: to foster environmental excellence by business world-wide. Within this major mission, the organization has five overarching goals:

- To stimulate, assemble, create, promote, and share, critical thinking on the subject of environmental management. 